\title{
PENGEMBANGAN BAHAN AJAR KOMIK PADA MATERI SISTEM TRANSPORTASI MAKHLUK HIDUP UNTUK MENUMBUHKAN MINAT BACA DAN MENINGKATKAN HASIL BELAJAR
}

\author{
Abdul Wahab'), Wasis' ${ }^{2)}$, Sifak Indana ${ }^{3)}$ \\ ${ }^{1)}$ Mahasiswa Program Studi Pendidikan Sains, Program Pascasarjana Universitas Negeri Surabaya \\ ${ }^{2), 3)}$ Dosen Pascasarjana Prodi Pendidikan Sains Univesrtitas Negeri Surabaya \\ E-mail: all.fisikawan@gmail.com
}

\begin{abstract}
Abstrak: Salah satu indikator keberhasilan suatu proses belajar mengajar IPA adalah tercapainya hasil belajar peserta didik baik kompetensi spiritual, sosial, pengetahuan dan keterampilan. Banyak faktor yang membuat hasil belajar ini rendah di antaranya adalah minat baca terhadap matapelajaran IPA masih rendah dan bahan ajar IPA yang tersedia tidak mencukupi serta bersifat monoton. Penelitian ini bertujuan untuk menghasilkan bahan ajar komik pada materi sistem transportasi makhluk hidup yang valid, praktis, dan efektif sehingga mampu menumbuhkan minat baca dan meningkatkan hasil belajar. Pendekatan pembelajaran yang digunakan untuk menerapkan bahan ajar komik ini adalah pendekatan saintifik sesuai anjuran Kurikulum 2013. Pengembangan bahan ajar menggunakan model 4D dan desain penelitian menggunakan one group pre-test post-test design. Penelitian dilaksanakan pada peserta didik kelas VIII SMP Negeri 1 Sekar Bojonegoro. Teknik analisis data menggunakan deskriptif kualitatif. Hasil analisis data penelitian menunjukkan bahwa: (1) bahan ajar yang dikembangkan valid, praktis dan efektif; (2) pembelajaran terlaksana dengan kategori baik; (3) peserta didik lebih aktif dalam pembelajaran; (4) minat baca peserta didik mengalami pertumbuhan dengan prosentase peningkatan 56,36\%; (5) hasil belajar peserta didik mengalami peningkatan dengan skor $\mathrm{N}$-gain berkategori tinggi. Berdasarkan hasil penelitian di atas, dapat disimpulkan bahwa bahan ajar komik yang telah dikembangkan valid, praktis, dan efektif untuk menumbuhkan minat baca dan meningkatkan hasil belajar peserta didik.
\end{abstract}

Kata kunci: Model Bahan Ajar Komik, Minat Baca dan Hasil Belajar.

\begin{abstract}
One indicator of the success of a learning process IPA is the achievement of learning outcomes of students both competence spiritual, social, knowledge and skills. Many factors make the results of this study are lower among reading of the science lesson is still low and science teaching materials available is insufficient and monotonous. This research aims to produce teaching materials on the comic material transportation system of living things are valid, practical, and effective so as to foster interest in reading and improve learning outcomes. Learning approach used to implement the teaching materials of this comic is the scientific approach as recommended by Curriculum 2013. The development of teaching materials using 4D models and design studies using one group pre-test post-test design. The experiment was conducted on students of class VIII SMPN 1 Sekar Bojonegoro. Data were analyzed using descriptive qualitative. The results of data analysis showed that: (1) a valid teaching materials developed, practical and effective; (2) study carried out by both categories; (3) more active learners in learning; (4) reading learners experiencing growth with a percentage increase of $56.36 \%$; (5) the study of students has increased by a score of $\mathrm{N}$-gain high category. Based on the above results, it can be concluded that the teaching materials have been developed comic valid, practical, and effective way to foster interest in reading and improve the learning outcomes of students.
\end{abstract}

Keywords: Subjects Comic, Reading Interest and Learning Outcomes.

\section{PENDAHULUAN}

Tata kelola kurikulum 2013 telah mengalami beberapa penguatan salah satu diantaranya adalah penguatan sarana dan prasarana untuk kepentingan manajemen dan proses pembelajaran. Salah satu sarana dan prasana dalam pembelajaran adalah bahan ajar yang cukup dan layak. SMP Negeri 1 Sekar merupakan salah satu sekolah yang berada di daerah pegunungan dan jauh dari kemajuan kota sehingga untuk memenuhi ketersedian bahan ajar sangat sulit dilakukan, selama ini bahan ajar yang digunakan hanya mengandalkan buku pembelian dari dana BOS sehingga setiap dua anak memegang satu buku dengan kondisi fisik buku kurang layak padahal keberadaan bahan ajar dalam pembelajaran merupakan faktor penting untuk mendukung keberhasilan suatu pendidikan khususnya pembelajaran di sekolah.

Peserta didik SMP Negeri 1 Sekar Bojonegoro ratarata berasal dari keluarga tidak mampu, berdasarkan data dari bagian Administrasi Sekolah (TU) diperoleh 
bahwa $80 \%$ wali murid bekerja sebagai buruh tani, $15 \%$ bekerja sebagai tani dan sisanya bekerja sebagai wiraswasta. Kaadaan perekonomian ini secara tidak langsung mempengaruhi keberadaan peserta didik sebagai contoh sarana dan prasana perserta didik sangat tidak lengkap. Mereka mengalami kesulitan dalam menganggarkan dana untuk pembelian buku atau bahan ajar diluar yang disediakan sekolah.

Berdasarkan hasil angket yang disebarkan pada 108 peserta didik SMP Negeri 1 Sekar Bojonegoro di peroleh data hanya $10,5 \%$ peserta didik yang mempunyai minat baca tinggi terhadap buku IPA sedangkan hasil ujian nasional yang diperoleh SMP Negeri 1 Sekar Bojonegoro pada tahun pelajaran 2013/2014 masih berkategori kurang dengan nilai D. Interview yang dilakukan terhadap 108 peserta didik mengenai bacan komik dihasilkan data $85 \%$ peserta didik menyukai bacaan komik, kemudian berdasarkan angket yang disebarkan peneliti $97 \%$ peserta didik sangat setuju apabila buku pelajaran IPA dibuat dalam bentuk komik.

Menurut Permendikbud No. 58 Tahun 2013 menjelaskan bahwa proses pembelajaran saat ini harus berpusat pada peserta didik dan guru hanya menjadi fasilitator dan bukan satu-satunya sumber belajar bagi peserta didik. Kenyataan ini tentunya menuntut seorang guru untuk lebih kreatif dan inovatif dalam melakukan pembelajaran dikelas sedangkan dari segi peserta didik, guru bukan satu-satunya sumber belajar mengharuskan peserta didik lebih aktif dalam mencari sumber belajar lain salah satunya adalah bahan ajar atau buku pelajaran. Peserta didik yang aktif tentunya harus didukung oleh beberapa faktor baik faktor dari dalam dan faktor dari luar. Faktor dari dalam salah satunya adalah minat baca yang tinggi karena sangat sulit memahami sumber belajar kalau minat baca peserta didik rendah sedangkan faktor dari luar salah satunya tersedianya bahan ajar yang menarik dan layak bagi peserta didik sehingga mereka bisa membaca dalam kondisi yang senang dan santai.

Penelitian ini tergolong penelitian pengembangan bertujuan untuk mengembangkan sebuah bahan ajar komik yang valid, praktis dan efektif sehingga dapat digunakan sebagai buku pegangan peserta didik dan guru IPA yang lainnya. Kevalidan bahan ajar komik ditentukan dari hasil validasi oleh pakar, kepraktisan ditunjukkan dari keterlaksanaan pembelajaran dan aktivitas peserta didik selama pembelajaran dan keefektifan ditentukan dari hasil belajar yang dicapai oleh peserta didik baik hasil belajar kompetensi sikap, kompetensi pengetahuan dan kompetensi keterampilan.

Manfaat penelitian ini dapat dirasakan oleh beberapa pihak antara lain: 1) bagi guru, bahan ajar komik ini dapat digunakan dalam membantu para guru dalam pembelajaran khususnya pada materi sistem transportasi dan 2) bagi peserta didik, dapat menumbuhkan minat baca peserta didik terhadap matapelajaran IPA sehingga diharapkan hasil belajar mereka bisa meningkat. Manfaat lain adalah bagi peneliti yang ingin mengembangkan bahan ajar yang menarik dan disukai oleh peserta didik bisa menggunakan bahan ajar komik ini sebagai salah satu literatur atau contoh sehingga hasil penelitiannya bisa lebih sempurna.

Pengembangan bahan ajar komik dewasa ini telah medapat perhatian dari berbagai kalangan, pada tahun 2011 Derektorat Pembinaan Sekolah Menengah Pertama telah menerbitkan beberapa buku ajar komik mata pelajaran IPA dengan materi yang masih terpisah antara materi Fisika dan Materi Biologi. Muhtaroh (2012) melakukan sebuah penelitian dan hasilnya menunjukkan bahwa pengembangan komik sebagai media pembelajaran Fisika mampu meningkatkan lama membaca peserta didik dari 1-2 jam perminggu menjadi 5-7 jam perminggu. Penelitian Rohmah (2015) menghasilkan sebuah kesimpulan bahwa peserta didik menunjukkan respon yang sangat baik pada bahan ajar yang dikembangkan dalam bentuk komik.

Menurut Denise (2007) penggunaan komik dalam pembelajaran mampu menarik peserta didik yang enggan membaca lambat laun menjadi suka membaca dan akhirnya mampu membaca buku biasa yang penuh dengan tulisan. Penggunaan komik merupakan salah satu cara baru dalam memotivasi peserta didik dan membantu peserta didik dalam mengembangkan potensi yang ada di dalam diri mereka (Orets, 2012). Anak-anak yang mempunyai kemampuan membaca terbataspun dapat dibantu dengan menggunakan bahan ajar komik, menurut Cheesman (2006) komik dapat digunakan untuk menilai pemahaman konsep peserta didik terhadap Ilmu Pengetahuan Alam dan dapat digunakan untuk mendapatkan perhatian peserta didik, mengenalkan topik baru, merangsang pemikiran kritis dan melatihkan etika atau sopan santun saat diskusi di kelas.

Berdasarkan uraian di atas maka dipandang perlu bagi peneliti untuk mengembangkan sebuah bahan ajar komik pada materi sistem transportasi makhluk hidup yang layak sehingga mampu menumbuhkan minat baca dan meningkatkan hasil belajar peserta didik.

\section{METODE PENELITIAN}

Desain pengembangan bahan ajar komik yang digunakan dalam penelitian ini adalah model pengembangan 4D. Sesuai dengan namanya, model pengembangan 4D terdiri dari 4 tahap pengembangan yaitu Define, Design, develop dan disseminate. Kempat tahap tersebut tidak digunakan seluruhnya dalam penelitian pengembangan bahan ajar komik ini tetapi hanya 3 tahap saja yaitu Define, Design dan develop 
untuk tahap Desseminate tidak dilakukan dengan pertimbangan waktu penelitian dan biaya yang diperlukan dalam penelitian.

Tahap Define dilakukan melalui empat sub tahap yaitu analisis tugas, analisis kurikulum, analisis konsep dan analisis peserta didik. Pada analisis tugas bertujuan untuk menentukan isi satuan pelajaran dengan cara mengidentifikasi dan merinci materi dalam bentuk garis besar mengacu pada Permendikbud No. 58 Tahun 2013 lampiran II dan buku pegangan Guru kurikulum 2013 yaitu materi sistem transportasi makhluk hidup. Analisis kurkulum memberikan gambaran secara umum masalah yang akan dihadapi peneliti dan solusi yang mungkin ditempuh untuk mengatasi masalah tersebut sedangkan analisis konsep bertujuan untuk mengidentifikasi konsep-konsep utama yang akan diajarkan selama penelitian secara rinci dan sistematis. Sub tahap terakhir analisis peserta didik bertujuan untuk mengetahui karakteristik peserta didik yang akan digunakan sebagai wahana melakukan penelitian bahan ajar yang digunakan, hasil analisis peserta didik ini akan membantu peneliti menentukan strategi yang harus digunakan dalam pembelajaran selama penelitian berlangsung.
Tahap Design dilakukan melalui beberapa sub tahap antara lain: 1) peneliti membuat story board, 2) membuat sketsa komik pada kertas A4 berdasarkan story board yang sudah divalidasi, 3) penintaan menggunakan program manga studio ex 4 pada sketsa yang telah discan dalam bentuk jpg, 4) pewarnaan menggunakan manga studio ex 4 terhadap sketsa yang telah dibuat di dalam komputer dan 5) tahap lettering yaitu memberikan balon dialog sesuai dengan cerita yang dibuat dalam story board.

Tahap develop merupakan tahap akhir dalam penelitian ini, bahan ajar komik yang sudah selesai kemudian divalidasi dan dilakukan beberapa revisi kemudian hasil akhirnya diimplementasikan pada 28 peserta didik kelas VIII SMP Negeri 1 Sekar Bojonegoro. Pengembangan yang dilakukan bukan hanya bahan ajar komik tetapi perangkat lain yang diperlukan dalam penelitian juga dikembangkan antara lain: Silabus, Rencana Pembelajaran, Lembar Kerja Peserta didik, Intrumen minat baca, Instrumen penilaian hasil belajar dan lembar observasi keterlaksanaan pembelajaran serta aktivitas peserta didik.

Secara ringkas alur pengembangan menggunakan model 4D dapat dilihat pada Gambar 1.

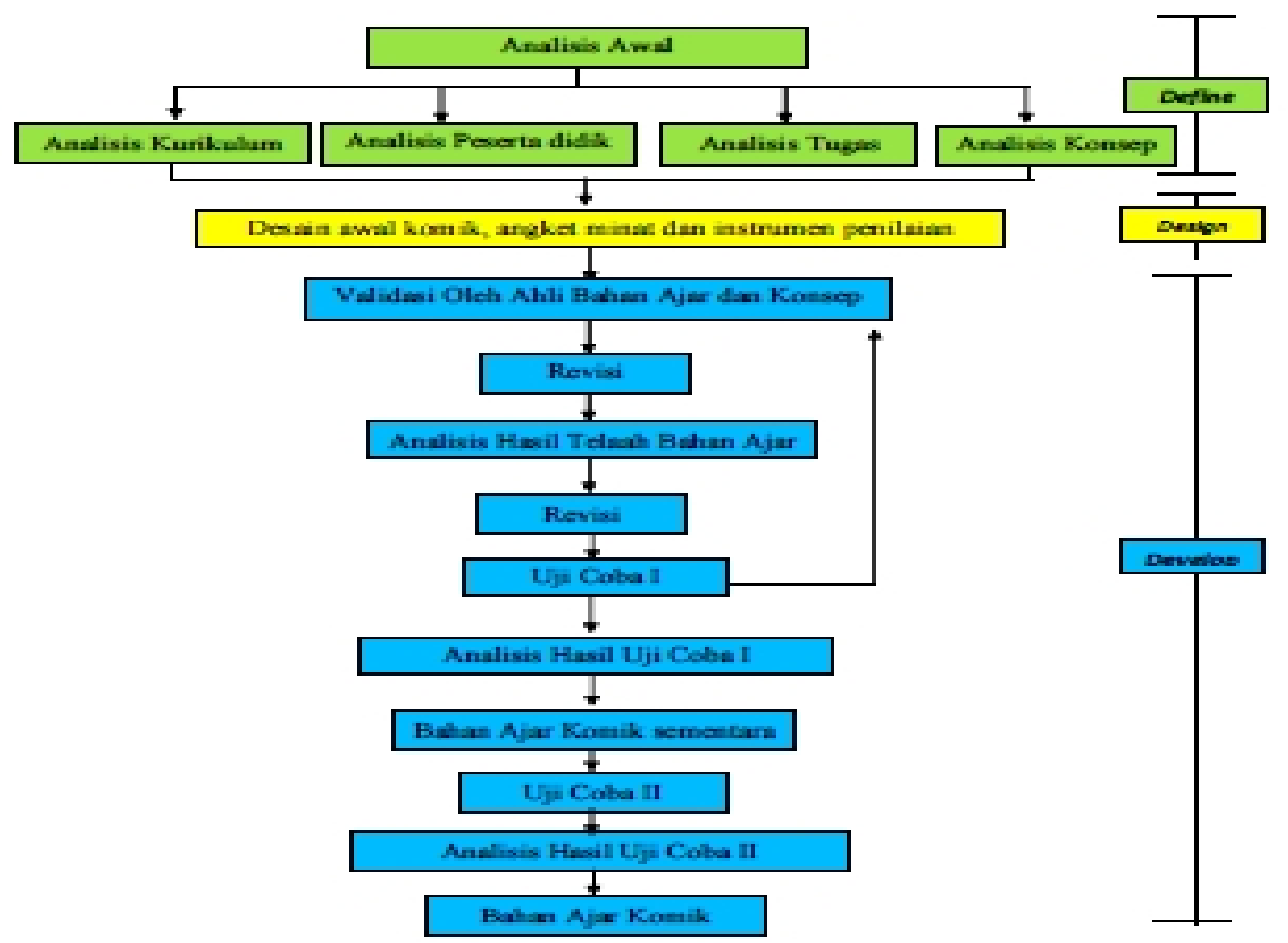

Gambar 1. Model pengembangan bahan ajar komik, adaptasi dari Thiagarajan (1974)

Rancangan penelitian menggunakan desain onegroup pretest-posttest (Millan, 2001). Penelitian dilakukan pada satu kelas eksperimen yang menjadi sampel dalam penelitian tanpa kelas pembanding. Pada desain one-group pretest - posttest kelompok sampel tunggal diberikan pretest/awal (O1) kemudian diberikan perlakuan (X) dan diakhir pembelajaran diberikan posttest/ tes akhir (O2). Bentuk dari desain one-group pretest -posttest dapat dilihat pada Gambar 2. 




Gambar 2. Desain penelitian One-group PretestPosttest.

Keterangan:

$$
\begin{aligned}
\mathrm{O}_{1}= & \text { Tes awal (Pretest) } \\
\mathrm{O}_{2}= & \text { Tes akhir (Posttest) } \\
\mathrm{X}= & \text { Penerapan bahan ajar komik dalam } \\
& \text { pembelajaran. }
\end{aligned}
$$

Variabel yang digunakan dalam penelitian ini antara lain: 1) validitas bahan ajar, 2) keterlaksanaan pembelajaran, 3) aktivitas peserta didik, 4) minat baca dan 5) hasil belajar. Validitas bahan ajar merupakan kelayakan bahan ajar komik yang telah divalidasi oleh dua validator, keterlaksanaan pembelajaran adalah penilaian terhadap kualitas pelaksanaan pembelajaran menggunakan bahan ajar komik. Semua kegiatan yang dilakukan peserta didik diamati dan dimasukkan ke dalam hasil pengamatan aktivitas peserta didik. Minat baca yang diamati merupakan kecenderungan peserta didik untuk membaca bahan ajar komik dengan hati yang senang dan tanpa paksaan dari dunia luar.

Hasil belajar yang di tes dalam penelitian ini meliputi kompetensi sikap spritual dan sikap sosial, kompetensi pengetahuan dan kompetensi keterampilan. Kompetensi sikap spiritual diukur menggunakan instrumen penilaian diri sedangkan kompetensi sikap sosial diukur menggunakan instrumen penilaian antar peserta didik. Kompetensi pengetahuan diukur menggunakan tes tulis pilihan ganda dan kompetensi keterampilan diukur menggunakan tes kinerja. Secara umum instrumen dalam penelitian ini antara lain: lembar validasi bahan ajar komik, lembar pengamatan keterlaksanaan pembelajaran, lembar pengamatan aktivitas peserta didik, angket minat baca, dan lembar tes hasil belajar.

Data yang diperoleh kemudian dianalisis secara deskriptif. Analisis validitas bahan ajar menggunakan analisis statistik percentage of agreement yang ditunjukkan oleh pesamaan:

$$
R=\left\{\frac{A}{A+D}\right\} \times 100 \%
$$

Keterangan :

$$
\begin{aligned}
& \mathrm{R}=\text { reliabitas instrumen } \\
& \mathrm{A}=\text { Frekuensi kecocokan antar penilai } \\
& \mathrm{D}=\text { Ketidak cocokan antar penilai. }
\end{aligned}
$$

Kriteria penentuan reliabilitas persentase kecocokan menurut Watkins (2001) adalah jika $\mathrm{R}<40 \%$ maka dinyatakan tidak baik, jika $40 \%<\mathrm{R} \leq 60 \%$ maka dinyatakan cukup baik, jika $60 \%<\mathrm{R} \leq 75 \%$ maka dinyatakan baik dan jika $\mathrm{R}>75 \%$ maka dinyatakan sangat baik sedangkan menurut Borich (Ibrahim, 2005) instrumen dikatakan reliabel jika penilaian reliabilitasnya $\geq 75 \%$.

Hasil pengamatan keterlaksanaan pembelajaran dianalisis menggunakan diskriptif kualitatif dengan teknik persentase yang dinyatakan dalam persamaan:

$$
P=\frac{E_{A} A}{\sum_{N}} x 100 \%
$$

Keterangan:

$\mathrm{P}=$ Persentase keterlaksanaan pembelajaran

$\sum \mathrm{A}=$ Aspek yang terlaksana

$\sum \mathrm{N}=$ Jumlah keseluruhan aspek yang diamati.

Aktivitas peserta didik diamati oleh dua pengamat menggunakan lembar observasi dan hasil kedua pengamat tersebut dianalisis menggunakan deskriptif kualitatif dengan menggunakan persamaan:

$$
P=\frac{F}{N} \times 100 \%
$$

Keterangan:

$$
\begin{aligned}
& \mathrm{P}=\text { Persentase } \\
& \mathrm{F}=\text { Frekuensi dalam satu menit aktivitas peserta } \\
& \quad \text { didik yang teramati } \\
& \mathrm{N}=\text { Jumlah seluruh aktivitas dalam satu menit. }
\end{aligned}
$$

Data minat baca yang diperoleh kemudian dianalisis dengan cara meminta peserta didik mengisi angket minat baca kemudian dianalis secara deskriptif kualitatis menggunkan persamaan:

$$
P=\frac{\sum R}{\sum N} \times 100 \%
$$

Keterangan:

$\mathrm{P}=$ Persentase minat baca peserta didik,

$\sum \mathrm{R}=$ Jumlah skor minat baca yang diisi oleh peserta didik

$\sum \mathrm{N}=$ jumlah skor total minat baca yang diberikan di angket.

Peningkatan hasil belajar dianalisis menggunakan $\mathrm{N}-\mathrm{g}$ dinormalisasi dengan persamaan

$$
N-y-\frac{\left(S_{\text {post }}\right)-\left(S_{\text {tre }}\right)}{100-\left(S_{\text {pre }}\right)}
$$

$$
\begin{aligned}
& \text { Keterangan: } \\
& \text { N-g = Peningkatan hasil belajar, } \\
& \text { Spre = Rata-rata pretest }(\%) \\
& \text { Spost }=\text { Rata-rata posttest }(\%)
\end{aligned}
$$

Sedangkan kategori n-gain dapat ditentukan sebagai berikut: jika $\mathrm{N}-\mathrm{g}>7$ maka dinyatakan berkategori tinggi, jika $7 \geq \mathrm{N}-\mathrm{g}>0,3$ maka dinyatakan berkategori sedang dan jikan $\mathrm{N}-\mathrm{g} \leq 0,3$ maka dinyatakan berkategori rendah. 


\section{HASIL PENELITIAN DAN DISKUSI}

Penelitian ini difokuskan pada pengembangan bahan ajar komik namun tetap dilengkapi dengan perangkat pembelajaran lain yaitu Rencana pelakasanaan pembelajaran, lembar kerja peserta didik, instrumen minat baca dan instrumen penilaian hasil belajar.

\section{A. Validitas Bahan Ajar Komik dan Perangkat Pembelajaran Pendukung}

Bahan ajar komik yang telah selesai dikembangkan kemudian divalidasi oleh dua validator dari segi materi dan dari segi media. Hasil penilaian validasi dari kedua validator diperoleh dari segi materi bahan ajar yang dikembangkan mendapat skor rata-rata 4,2 dan dari segi media mendapat skor rata-rata 4,5 dengan kategori sangat valid (Ratumanan, 2006) sedangkan rata-rata reliabilitas bahan ajar komik dari segi materi sebesar 96,9\% dan dari segi media sebesar 95,6\%. Hasil ini memberikan gambaran bahwa bahan ajar yang dikembangkan dapat dinyatakan valid dan layak sebagai buku pegangan peserta didik.

Perangkat pendukung dalam penelitian yang telah dikembangkan juga divalidasi oleh dua validator dan menghasilkan data sebagai berikut: 1) Rencana pelaksanaan pembelajaran diperoleh hasil penilaian dengan skor rata-rata sebesar 3,7 berkategori sangat valid dan reliabilitasnya sebesar 96,3\%, 2) Lembar kerja peserta didik setelah divalidasi diperoleh hasil penilaian dengan nilai rata-rata sebesar 3,4 berkategori valid dengan reliabilitas sebesar 87,0\%\%, 3) Instrumen minat baca dengan hasil penilaian rata-rata sebesar 3,5 berkategori valid dengan reliabilitas sebesar 90,4\%, 4) Instrumen tes kompetensi pengetahuan dengan hasil penilaian rata-rata sebesar 3,5 berkategori valid dengan reliabilitas sebesar 88,7\%, 5) Instrumen tes kompetensi keterampilan dengan hasi penilaian rata-rata sebesar 3,7 berkategori sangat valid dan reliabilitas sebesar 91,3\% dan 6) Lembar pengamatan sikap peserta didik dengan hasil penilaian rata-rata sebesar 3,67 berkategori sangat valid sedangkan reliabilitas lembar pengamatan peserta didik dari segi bahasa sebesar $87,5 \%$ dan dari segi isi sebesar $92,5 \%$.

\section{B. Keterlaksanaan Pembelajaran}

Pengamatan terhadap keterlaksanaan rencana pelaksanaan pembelajaran dilakukan oleh dua pengamat selama 5 kali pertemuan didapatkan data seperti ditunjukkan pada Gambar 3.

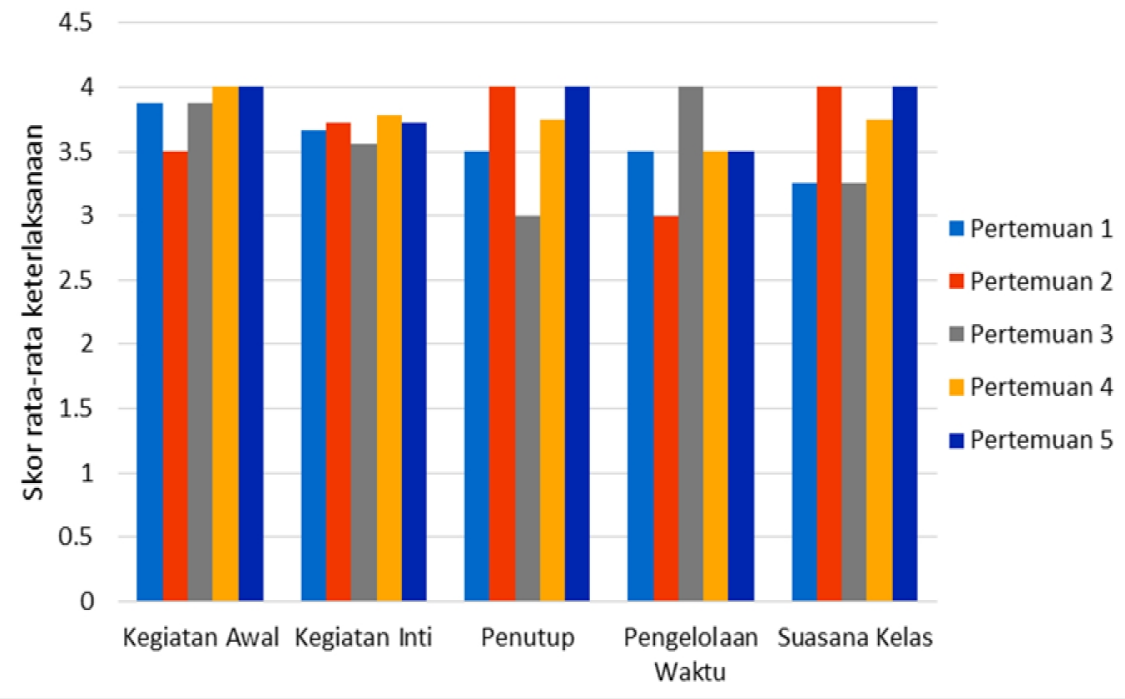

Gambar 3. Hasil pengamatan keterlaksanaan pembelajaran

Berdasarkan Gambar 3 dan analisis keterlaksanaan rencana pelaksanaan pembelajaran yang diamati oleh dua pengamat sebagai penerapan pengembangan rencana pelaksanaan pembelajaran dalam mendukung penggunaan bahan ajar komik diperoleh bahwa semua tahap-tahap yang ada pada rencana pelaksanaan pembelajaran sudah terlaksana dengan skor rata-rata sebesar 3,7 berkategori baik dan reliabilitas keterlaksanaan pembelajaran sebesar 96,35\%.

Tahapan pada rencana pelaksanaan pembelajaran terdiri dari 3 tahap utama yaitu pendahuluan, kegiatan inti dan penutup. Pada tahap utama dalam rencana pelaksanaan pembelajaran yang dikembangkan sudah mengakomodir kegiatan membaca bahan ajar komik dengan sintak pembelajaran menggunakan pendekatan saintifik. Terlaksananya semua tahapan dalam rencana pelaksanaan pembelajaran selama penelitian membuat skor rata-rata keterlaksanaan pembelajaran yang diperoleh tinggi.

\section{Aktivitas Peserta Didik}

Hasil pengamatan terhadap aktivitas peserta didik dalam penelitian dilakukan oleh dua pengamat selama 5 kali pertemuan secara ringkas dapat dilihat pada Gambar 4. 


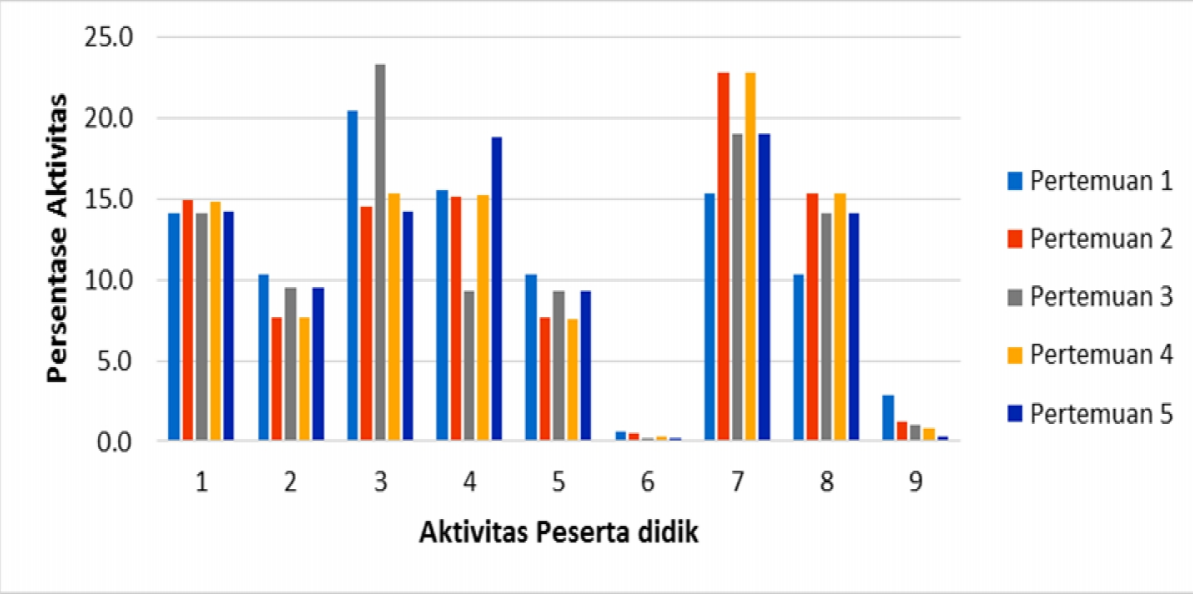

Gambar 4. Hasil pengamatan aktivitas peserta didik

Aktivitas peserta didik yang diamati selama pembelajaran terdiri dari 9 aktivitas yaitu: 1) melakukan pengamata, 2) menyusun pertanyaan, 3) melakukan kegiatan penyelidikan / simulasi, 4) membaca bahan ajar komik, 5) menjawab pertanyaan pada LKP, 6) bertanya kepada guru jika membutuhkan bimbingan, 7) mengkomunikasikan hasil kegiatan, 8) menyimpulkan hasil pembelajaran dan 9) tindakan yang tidak relevan.

Berdasarkan Gambar 4 dan hasil analisis pengamatan aktivitas peserta didik selama pembelajaran diperoleh reliabilitas pengamatan sebesar $99,1 \%$ dan semua aktivitas peserta didik sudah sesuai dengan sintak pada pendekatan saintifik yang digunakan dalam penelitian. Aktivitas - aktivitas pada Gambar 4 memberi gambaran bahwa peserta didik sangat aktif selama pembelajaran, mereka melakukan kegiatan secara mandiri dengan sedikit bimbingan dan berinteraksi dengan sesama peserta didik. Interaksi sosial dalam pembelajaran mampu mengembangkan kognitif peserta didik, hal ini sejalan dengan pendapat Vygostky bahwa perkembangan proses dalam hidup bergantung pada interaksi sosial dan pembelajaran sosial berperan penting dalam perkembangan kognitif seseorang (Khulthau \& Todd, 2008).

Peserta didik menunjukkan ekspresi senang saat aktivitas membaca komik berlangsung, mereka membaca dengan antusias tak terlihat rasa bosan di wajah mereka, kondisi ini dapat dilihat pada Gambar 4 dimana aktivitas membaca bahan ajar komik menjadi salah satu aktivitas yang menonjol selama pembelajaran. Aktivitas membaca bahan ajar komik melatihkan peserta didik menyukai membaca buku pelajaran dan membantu mereka menemukan inti materi dengan cepat dan mengingat informasi pada bacaan lebih mudah bila dibandingkan dengan buku pelajaran IPA biasa. Menurut Alison (2015) menjelaskan bahwa informasi yang kompleks dapat lebih mudah diserap melalui kombinasi kata-kata dan gambar bahkan komik mampu mendorong seseorang membaca tanpa terintimidasi oleh tanda-tanda baca dalam suatu bacaan.

\section{Minat Baca Peserta Didik}

Minat baca peserta didik diperoleh dari hasil pengisian angket minat baca yang diberikan disetiap akhir pertemuan dengan tujuan untuk mengetahui secara detail persentase pertumbuhan minat baca mulai pertemuan pertema hingga pertemuan terakhir. Hasil analisis minat baca secara ringkas ditunjukkan pada Gambar 5.

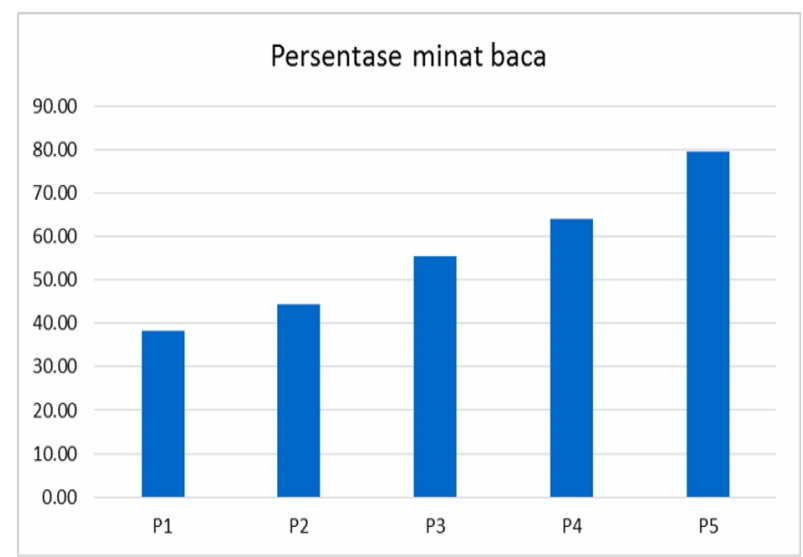

Gambar 5. Persentase minat baca peserta didik

Berdasarkan Gambar 5 dan analisis angket minat baca peserta didik diperoleh hasil bahwa ada pertumbuhan minat baca dari pertemuan pertama hingga pertemuan kelima yang ditunjukkan dari peningkatan persentase skor minat baca peserta didik. Rata-rata persentase peningkatan minat baca secara keseluruhan sebesar 56,36\% dan jika diamati peningkatan tiap pertemuan didapatkan rata-rata persentase sekitar 10,5\%. Hal ini disebabkan semakin lama ketertarikan peserta didik terhadap bahan ajar semakin besar dan peserta didik merasa senang membaca bahan ajar komik.

Menurut Zimmerman (2008) peserta didik yang kemampuan membacanya terbatas akan lebih mudah memahami isi suatu bacaan melalu media komik 
dibandingkan dari sebuah buku yang berisi berpuluhpuluh paragraf, dalam komik hanya dibutuhkan beberapa kata dan gambar untuk menjelaskan satu materi dan itu tidak bisa dilakukan pada buku pelajaran biasa. Kondisi seperti inilah yang membuat para peserta didik lebih mudah memahami materi pada bahan ajar komik dibandingkan materi pada buku pelajaran IPA biasa.

\section{E. Hasil Belajar Kompetensi Sikap Spiritual}

Hasil analisis tes kompetensi sikap spiritual yang dilakukan dengan penilaian diri pada indikator menunjukkan sikap bersyukur kepada Allah SWT sebagai wujud pengamalan ajaran agama Islam dalam setiap pertemuan selama penelitian menunjukkan perkembangan yang baik, secara ringkas dapat diperhatikan pada Gambar 6.

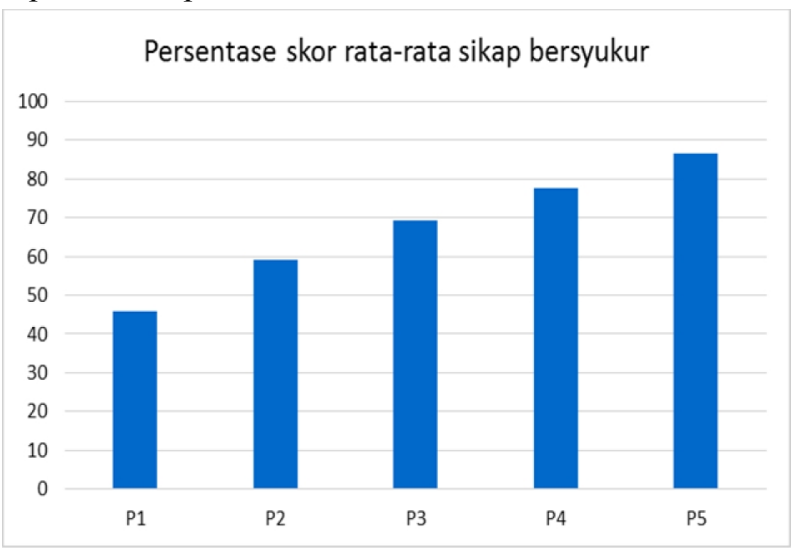

Gambar 6. Persentase skor rata-rata sikap spiritual

Kompetensi sikap spiritual yang diamati dan dinilai dalam penelitian ini terbatas pada indikator menunjukkan sikap bersyukur kepada Allah SWT sebagai bentuk pengamalan ajaran Agama Islam sedangkan indikator bersyukur sendiri dibagi menjadi 4 indikator yaitu 1) mengucapkan atau membaca "bismillah" sebelum melakukan sesuatu, 2) mengucapkan "subhanaallah" ketika menemukan halhal yang menarik, 3) mengucapkan "Alhamdulillah" ketika selesai mengerjakan semua kegiatan dan 4) menunjukkan ekspresi senang setiap mengikuti pembelajaran.

Skor rata-rata sikap bersyukur yang teramati selama 5 kali pertemuan sebesar $67,67 \%$ dengan kategori baik. Peningkatan ini tidak terlepas dari pemuatan sikap spiritual dalam bahan ajar komik yang mengajak peserta didik membiasakan diri membaca "Basmallah" ketika memulai suatu pekerjaan, membaca "Subahanaallah" ketika bertemua dengan sesuatu yang menajubkan dan membaca "Alhamdulillah" ketika selesai melakukan suatu pekerjaan. Desain bahan ajar yang menarik juga mampu mengkondisikan peserta didik membaca dalam kondisi senang dan santai.

\section{F. Hasil Belajar Kompetensi Sikap Sosial}

Sikap sosial yang diamati atau dinilai dalam penelitian ini terbatas pada dua sikap saja yaitu sikap jujur dan sikap menghormati teman lain. Hasil analisis tes penilaian antar peserta didik terhadap kedua sikap sosial ini didapatkan skor rata-rata persentase sikap jujur sebesar $66,12 \%$ dan skor rata-rata persentase sebesar $67,50 \%$ dengan kategori baik (Kemendikbud, 2014). Secara ringkas dapat dilihat pada Gambar 7 dan Gambar 8.

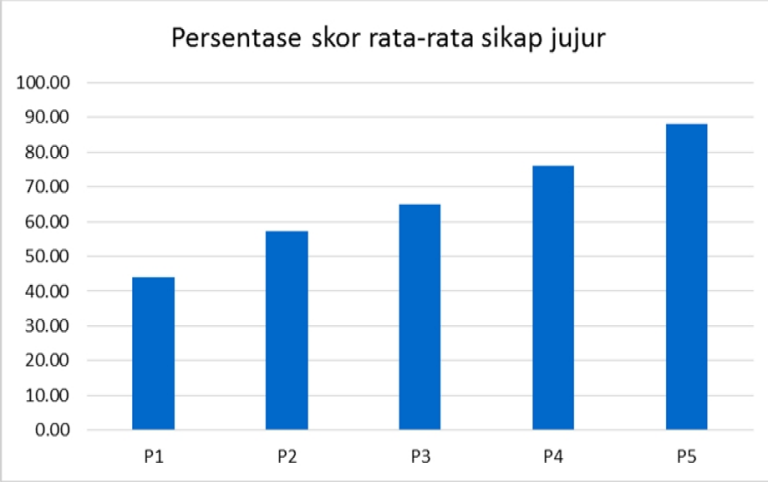

Gambar 7. Persentase peningkatan sikap jujur selama 5 kali pertemuan.

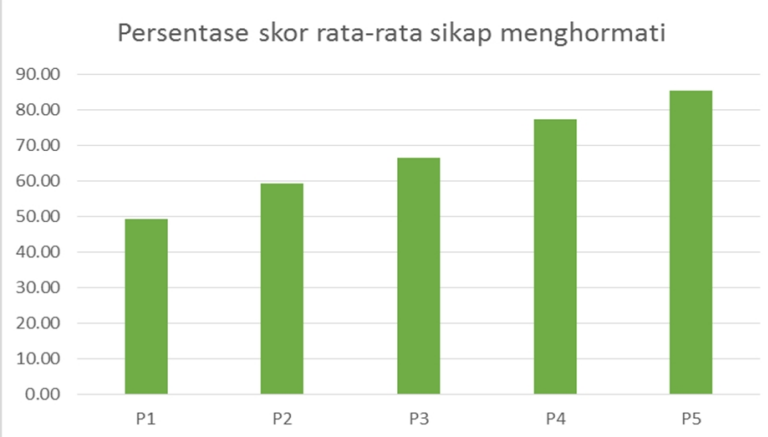

Gambar 8. Persentase peningkatan sikap menghormari orang lain selama 5 kali pertemuan.

Berdasarkan Gambar 7 dan Gambar 8 dapat dijelaskan bahwa sikap sosial baik sikap jujur dan mengormati orang lain mengalami peningkatan dari pertemuan pertama hingga pertemuan kelima. Peningkatan sikap jujur tidak terlepas dari peran serta bahan ajar komik yaitu dengan cara menyajikan materi dalam bentuk gambar telah memudahkan peserta didik memahami materi dengan jelas, pemahaman ini berimplikasi terhadap peningkatan kepercayaan diri sehingga mereka tidak perlu lagi melihat jawaban dari kelompok yang lain dan tanpa mereka sadari kepercayaan diri ini telah menghilangkan kesenjangan akibat perbedaan kemampuan yang dimiliki tiap peserta didik dan menuntun mereka melakukan setiap kegiatan dengan jujur. Menurut Bronzo (2013) penggunaan komik dalam pembelajaran mampu menghilangkan kesenjangan yang disebabkan perbedaan kemampuan akademik setiap peserta didik. 
Pembicaraan tokoh dalam bahan ajar komik yang selalu meminta ijin sebelum bertanya menjadi salah satu peran bahan ajar komik dalam meningkatkan sikap menghormati orang lain, secara perlahan sikap meminta ijin sebelum bertanya mulai terbentuk dari pertemuan pertama dan semakin baik ketika pertemuan kelima dimana peserta didik sudah terbiasa selalu meminta ijin ketika hendak bertanya atau hendak menyampaikan pendapat mereka selama kegiatan mengkomunikasikan hasil kegiatan berlangsung. Kathryn (2015) menjelaskan bahwa meminta peserta didik membaca komik mampu mendorong mereka melakukan penemuan, pemecahan masalah, membuat desain, dan secara mendasar membaca komik mampu mempengaruhi sikap peserta didik.

\section{G. Hasil Belajar Kompetensi Pengetahuan}

Pengukuran kompetensi pengetahuan peserta didik dilakukan menggunakan instrumen tes kompetensi pengetahuan berupa soal pilihan ganda sejumlah 26 butir soal. Pengukuran ini dilakukan dua kali yaitu sebelum diberi perlakuan (Pretest) digunakan untuk menentukan pengetahuan awal peserta didik terhadap materi yang akan diajarkan selama penelitian dan tes setelah diberi perlakukan (Posttest) digunakan untuk mengetahui apakah kompetensi pengetahuan peserta didik mengalami peningkatan setelah diberi perlakuan berupa bahan ajat komik. Secara ringkas hasil tes kompetensi pengetahuan dapat dilihat pada Gambar 9.

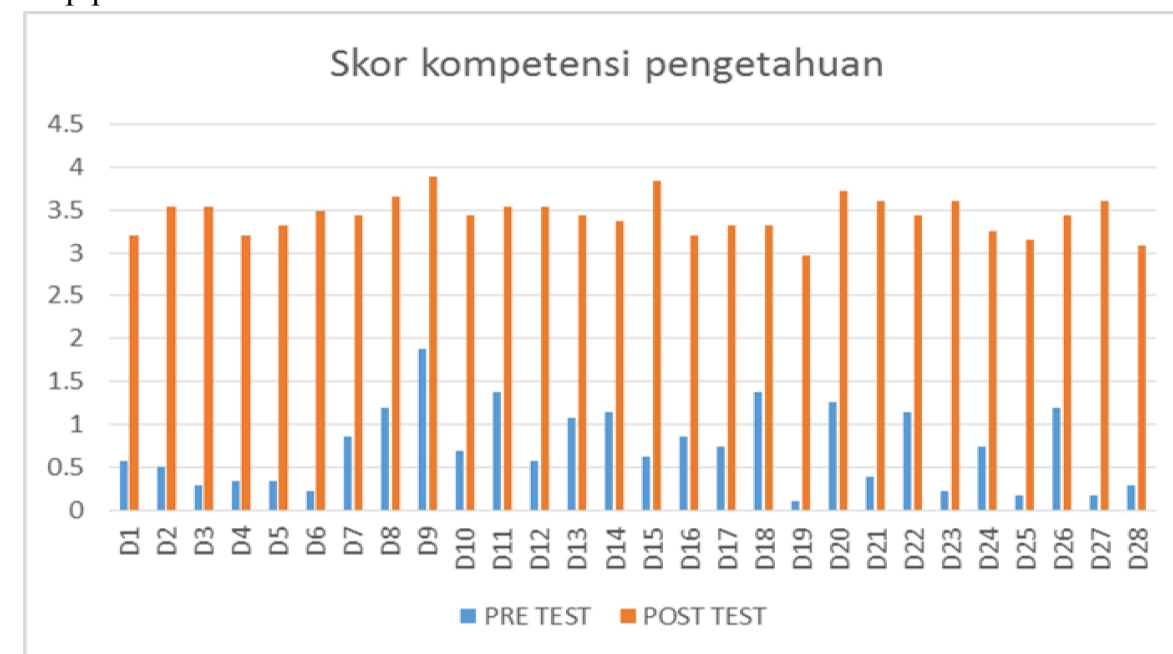

Gambar 9. Hasil analisis tes kompetensi pengetahuan peserta didik pretest dan posttest.

Berdasarkan Gambar 9 dan analisis hasil tes kompetensi pengetahuan diperoleh ada peningkatan hasil belajar peserta didik dengan n-gain sebesar 0,8 berkategori tinggi, sedangkan pencapaian ketuntasan indikator rata-rata sebesar 85,85 dan semua indikator tuntas baik secara klasikal maupun secara individual. Pada pretest ketuntasan belajar peserta didik adalah $0 \%$ yang artinya tidak satupun peserta didik yang tuntas setelah diberi prestest tentang materi sistem transportasi makhluk hidup, hal ini disebabkan peserta didik belum menerima materi sistem transportasi makhluk hidup dan mereka belum membaca bahan ajar tentang sistem transportasi makhluk hidup. Setelah diberi perlakuan yaitu penerapan bahan ajar komik dalam pembelajaran selama 5 kali pertemuan dengan menggunakan pendekatan saintifik kemudian peserta didik diminta menyelesaikan posttest diperoleh hasil bahwa ketuntutasan belajar peserta didik $100 \%$. Hal ini menunjukkan bahwa penerapan bahan ajar komik dalam pembelajaran menggunakan pendekatan saintifik mampu meningkatkan hasil belajar kompetensi pengetahuan peserta didik.
Peningkatan ini salah satu penyebabkan dikarenakan peserta didik merasa mudah menemukan ide atau inti materi dalam bahan ajar komik dan peserta didik mampu mengingat informasi yang ada dalam bahan ajar komik lebih lama dibandingkan ketika mereka membaca dari buku ajar biasa. Miller (2006) melakukan penelitian serupa dan menghasilkan data bahwa penggunaan komik dapat meningkatkan kemampuan peserta didik dalam memahami makna suatu kalimat dan membuat mereka mudah mengingat setiap informasi yang disajikan.

\section{H. Hasil Belajar Kompetensi Keterampilan}

Kompetensi keterampilan peserta didik diukur dengan menggunakan instrumen tes kinerja yang sudah divalidasi oleh dua validator sedangkan kompetensi keterampilan yang diukur adalah menyelidiki tekanan zat cair pada kedalaman tertentu dan menyelidiki tekanan zat cair pada ruang tertutup. Pengambilan tes keterampilan dilakukan sebanyak dua kali yaitu sebelum penelitian dengan memberikan pretest dan setelah penelitian dengan memberikan posttest. Hasil tes kompetensi keterampilan dapat dilihat pada Gambar 10 . 


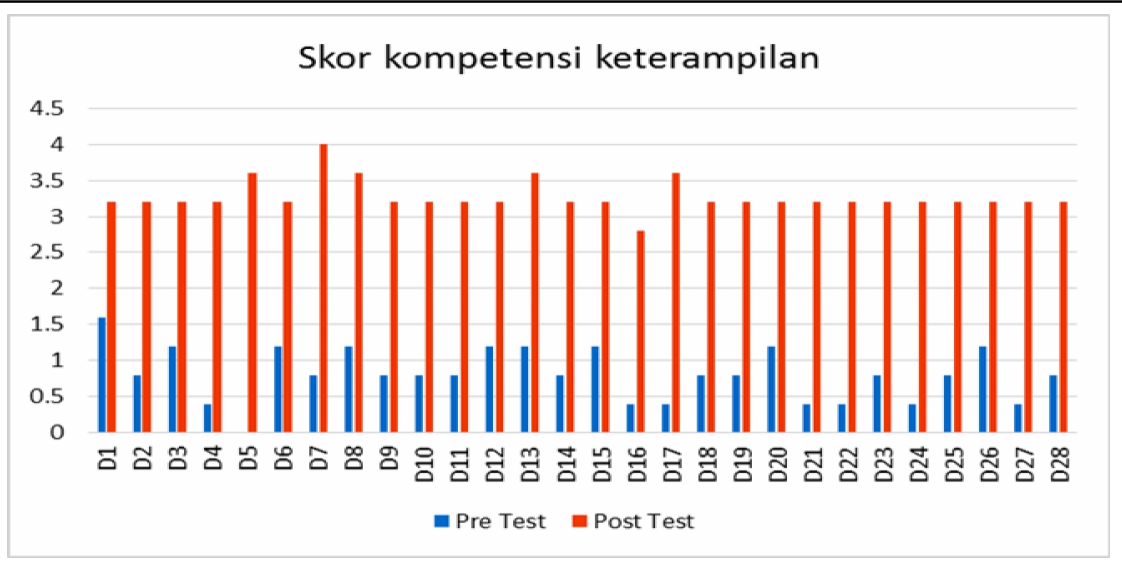

Gambar 10. Hasil tes kompetensi keterampilan saat pretest dan posttest.

Berdasarkan Gambar 10 dan analisis hasil tes kompetensi keterampilan didapatkan data bahwa ada peningkatan kompetensi keterampilan dengan n-gain sebesar 0,8 dengan kategori tinggi dan ketuntasan hasil belajar peserta didik kompetensi pengetahuan adalah $100 \%$. Peningkatan kompetensi keterampilan dikarenakan pada bahan ajar komik telah memuat dengan jelas kegiatan penyeledikan dalam bentuk gambar dan kata-kata sehingga peserta didik merasa sangat terbantu serta didukung oleh lembar kerja peserta didik yang didesain mendorong kemampuan penyelidikan mereka. Kombinasi antara bahan ajar komik dan lembar kerja peserta didik telah terbukti mampu meningkatkan hasil belajar kompetensi keterampilan pada materi sistem transportasi makhluk hidup.

\section{Temuan Penelitian}

Berdasarkan analisis hasil penelitian yang telah dilakukan diperkuat oleh kejadian-kejadian selama pembelajaran di dapat beberapa temuan antara lain:

a. Bahan ajar komik yang dikembangkan untuk menumbuhkanminat baca dan meningkatkan hasil belajar peserta didik dinyatakan valid dan dapat digunakan dalam pembelajaran IPA kelas VIII semester genap.

b. Bahan ajar komik yang dikembangkan dinyatakan praktis dengan melihat keterlaksanaan rencana pelaksanaan pembelajaran yang terlaksana dengan skor rata-rata sebesar 3,7 berkategori baik dan semua aktivitas peserta didik telah sesuai dengan sintaks pada pendekatan saintifik.

c. Bahan ajar komik yang dikembangkan dinyatakan efektif dengan mengacu peningkatan hasil belajar peserta didik antara lain: 1) hasil belajar kompetensi sikap spiritual mengalami peningkatan dengan skor persentase rata-rata sebesar $67,67 \%$, kompetensi sikap sosial mengalami peningkatan persentase ratarata sebesar $66,11 \%$ untuk sikap jujur dan $67,50 \%$ untuk sikap menghormati orang lain, 2) hasil belajar kompetensi pengetahuan mengalami peningkatan dengan $n$-gain sebesar 0,8 berkategori tinggi dan 3) kompetensi keterampilan mengalami peningkatan dengan n-gain sebesar 0,8 berkategori tinggi.

d. Penerapan bahan ajar komik dalam pembelajaran dengan pendekatan saintifik mampu menumbuhkan minat baca peserta didik dengan rata-rata persentase peningkatan sebesar $10,35 \%$ tiap pertemuan.

\section{KESIMPULAN}

\section{A. Simpulan}

Berdasakan hasil analisis, diskusi, dan pembahasan maka dapat disimpulkan bahwa bahan ajar komik yang dikembangkan sudah valid, praktis dan efektif sehingga layak digunakan untuk menumbuhkan minat baca dan meningkatkan hasil belajar peserta didik kelas VIII SMP Negeri 1 Sekar Bojonegoro pada materi sistem transportasi makhluk hidup.

\section{B. Saran}

Saran yang bisa disampaikan kepada peneliti lain adalah

1. Sebelum melakukan penelitian, berilah gambaran yang jelas kepada peserta didik tentang metode, model atau pendekatan yang akan digunakan peneliti selama pembelajaran.

2. Perlu dikembangkan bahan ajar komik pada materi lain karena bahan ajar komik mampu menumbuhkan minat baca dan meningkatkan hasil belajar peserta didik.

3. Sebelum melakukan penelitian menggunakan pendekatan saintifik sebaiknya melatih peserta didik kemampuan-kemampuan dasar yaitu mengamati, menaya, mengumpulkan informasi, menalar dan mengkomunikasikan.

\section{REFERENSI}

Alison, Flood. (2014). Comics laureate to be superhero of literacy: Gibbons names as first to hold role that uses graphic novels to promote reading. London: Guardian News \& Media Limited. 
Bronzo, William G. (2013). "From Mangan 2". Educational Leadership. Vol. 71. p58-61.

Cap, Orest. (2012). "Digital Comic in Human Ecology". International Journal in Learning. Vol. 19, p27-44.

Chessman, Kerry. (2006). "Using Comis in the Science Classroom". Journal of College Science Teaching. Vol. 35 Issue 4, p48-51. 4p.

Comer, Kathryn. (2015). "Illustrating Praxis: Comic Composition, Narrative Rhetoric, and Critical Multiliteracies". Composition Studies Spring. Vol. 43. p75-104.

Denise, Schipani. (2007). Comics boost reading skills. New York: Scolastic Inc.

Ibrahim, M. (2005). Assesmen Berkelanjutan. Surabaya: Unesa University Press.

Kemendikbud. (2014a). Peraturan Menteri Pendidikan dan Kebudayaan No. 58 Tahun 2014 tentang Kurikulum 2013 Sekolah Menengah Pertamal Madrasah Tsanawiyah. Jakarta: Kemendikbud.

Kuhlthau \& Todd. 2007. "Guided Inquiry: A framework for learning through school librariesin 21st century schools". New Jersey: CISSL. (Online). (http://cissl.scils.rutgers.edu/guided inquiry/introduction.html.htm. diakses tanggal 3 Juli 2014).

Milan Mc and Schumacher. (2001). Research in Education. London: Longman.
Miller, P.H. (2000). Theories of Developmental Pscychology. New York: W.H. Freeman and Company.

Mutaroh, dkk. (2012). "Pengembangan media komik sebagai media pembelajaran fisika untuk siswa SMA". "Prosiding seminar nasional fisika 2012”. Halaman 126-131.

Ratumanan, T.G. (2006). Evaluasi Hasil Belajar yang Relevan dengan Kurikulum Berbasis Kompetensi. Surabaya: Unesa University Press.

Rohmah. (2015). "Pengembangan komik sebagai media pembelajaran IPA kelas VIII SMP pada materi pokok sistem transportasi”. Jurnal Online Mahasiswa Universitas Riau. Vol. 2 No. 2.

Thiagarajan, S. Semmel, Dorothy S, Semmel, Melvyn I. (1974). Instructional Development for Training Teachers of Exceptional Children. Washington, DC: National Center for Improvement Educational.

Watkins, M.W anf Pacheco, M. (2001). "Interobserver Agreement in Behavioral Research: Importance anda Calculation". Journal of Behavioral Education, 10 (4) 205-212.

Zimmerman, Bill. (2008). Creating Comics Fosters Reading, Writing, and Creativity. Online laman www.eddigest.com. 